\title{
Green Crime and the Latent Functions of Bio- Agriculture and Biotechnology
}

\author{
Bijit Das ${ }^{1}$ and Joyanta Borbora ${ }^{2}$ \\ ${ }^{1} P h D$ Research Scholar, Department of Sociology, Dibrugarh University, Assam, India \\ ${ }^{2}$ Professor, Department of Sociology, Dibrugarh University Assam, India
}

\section{ABSTRACT}

The rampant proliferation of biotechnology into several aspects of our life from the past decade has lead to augmentation of debates and discourses within various consumer goods and agricultural sector. The following paper rejuvenates a novel perspective of Biotechnology into the realm of the political economy of genetically modified food and grains. The following article subsequently looks into the discourse of political hegemony and dominance by the powerful corporate via powerful nations into the least powerful and poor countries for spreading the monopoly to dominate the global food markets. The article generates nodes on green crime, environmental conventions for the latent consequences of biotechnology.

\section{KEY WORDS: BIOTECHNOLOGY, GREEN CRIME, HEGEMONY, POLITICAL ECONOMY.}

\section{INTRODUCTION}

The concept of harm encompasses the realm of statecorporate crime taking into account the relationship of the harm with social, economic and political organs of our society and finally the relationships of harm with our society (Tombs, 2007) and (White, 2003) The proliferation of genetically modified organism into human society has long been remained contested for its optimism and pessimism. Optimism forfeits its revolutionary agenda of combating hunger across society and pessimism for its assemblance with corporate greed, polarizing hunger and governments, creating clouds authorities regimes of latent consequences. The debate looks into the illegal, unethical and harmful practices which keep agricultural biotechnology as a highly contested subject.

\section{ARTICLE INFORMATION}

Received 28th Oct 2020 Accepted after revision 15th Dec 2020 Print ISSN: 0974-6455 Online ISSN: 2321-4007 CODEN: BBRCBA

Thomson Reuters ISI Web of Science Clarivate Analytics USA and Crossref Indexed Journal

\section{Clarivate
Analytics}

NAAS Journal Score 2020 (4.31)

A Society of Science and Nature Publication,

Bhopal India 2020. All rights reserved.

Online Contents Available at: http//www.bbrc.in/

Doi: http://dx.doi.org/10.21786/bbrc/13.15/12
Hunger and starvation is something that haunts mankind for its existence. According to the report on food and agricultural organizations of the United Nations, 2004 millions of people suffer from malnutrition and starvation. The debate originates in the epistemological domains of opportunity versus aid, of which the greater agenda of combating the humanitarian crisis of hunger is to be seen with biotechnology's latent functions of upraising in commercial opportunity for another folk of people (Harle, 1978). A thin line anticipates the realm of risk and fear under the modesty of extension of relief policies, free trade and sustainable development. But little concentration islet upon the latent consequences of loss of biodiversity, economic hegemony and policies of world trade. Certain affluent countries of the west such as the United States, have forecasted the world supremacy and hegemony along with promoting GMO of the corporate under the veil of hunger (Mulaney, 2004).

Any instance of harm may be related to an act of nature or an anthropogenically induced harm which might lead to social harm at times. Law might acknowledge certain acts to be illegal but certain acts of legal activities also produce harm, which becomes the core of green criminology. This is why, the relationship of criminology and genetically modified food is found in the acknowledgement of

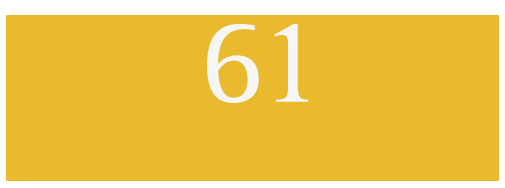


criminological agendas for the reported harms and risks with inequalities in the social and political discourses that challenge the existent priorities of governing bodies (Walters, 2006). The article looks into the criminological debate within agricultural biotechnology through two instances of Zambia and India.

What Is Green Criminology?: The focus of green criminology is to pay profound attention to areas given minimal importance in social science, such as harms generated to the living and the non-living by anthropogenic activities. Environmental issues have played a major important role in today's time, wherein 2020 the situation of COVID 19 pandemic is revealed as nature does its homeostasis through its ways, where the connections came to halt because of the SarsCOV-2 virus, bringing everybody into isolation and the situation of reduction of pollution, fuel prices falling, less consumption of fuel is the factories and industries have led to less carbon emission. The instance of filling the ozone hole has also come into effect. The alarming conditions of the climate crisis, global are warming were the news of everyone's life. Now the factors of environmental degradation have been affecting the lives of living species because of human activities. Our main focus of green criminology is to look into the matter of anthropocentric acts which affects the living and the nonliving.

White-collar crime was coined by Sutherland (Sutherland, 1983), which referred to an organised crime committed by the affluent class (ibid). The term Green Crime was coined by Michel James Lynch in 1990 (White, 2013) which refers to offences committed against nature which juxtaposes the offences against the living and the nonliving elements of nature, leading to harming the environment as such, encompassing environmental laws and regulations. Importance of green criminology is to try to prognosticate and anticipate calamities from occurring, as certain paradoxes could imply harm and destruction to life forms and geographical changes of the earth. The core of the study in green criminology is Harms. In criminological terms, there are always different instances of how harm is taken into consideration. Two considerations are taken in considering harm. One is the strict legal procedural approach and the other is the socio-legal approach. (Tapan, 1947), (Green and Ward, 2000).

In the purview of the strict legal approach, the harm is defined in considering legal definitions that look into acts that are implied by law. The strict legal approach focuses on acts beyond the limits of laws which are beyond the limits of legal definitions generated by the state, but acts which are legal in accordance to law but still potent of producing harm or taking the living and the nonliving components of the environment into jeopardy (Situ and Emmons, 1999). Harm becomes importance in Sociological discourse because certain social practices are considered as normal acts but lead to more serious forms of harm, such as waste disposal, genetic engineering, clear-felling, poaching etc, these acts might not be defined as criminal by nations but still pose a serious threat to the society and the ecosystem.

Between both the views taken in considering acts of criminality and harm, there is a thin line of invisible politics, which acts for negligible attention into the concrete manifestation of social inquiry, and obscuration of certain environmental damages which represents the culture of denial for environmentally unfriendly activities and consequences (Cohen, 1993). Greening of criminology becomes the need of the hour because environmental scholarship has been given less importance in criminology and other disciplines. The harmful impact on the humans, plants and animal species encompassing all the living and the nonliving forms in the earth should be given wide attention and take the socio-legal approach seriously, which applies to different ventures of concerning areas of theft of natural resources, dispossessing of the indigenous population from land and welfare, paradox of mono-cropping, contract farming leading to fading of farmers autonomy over seeds because of genetically modified seeds, food industry and agribusiness companies colonizing nature (Walters,2006).

\section{METHODOLOGY}

Two case studies of India and Zambia are taken to justify the latent functions of biotechnology and to work accordingly. Secondary data from previously existing works of literature are used to have an outlook upon the case of India and Zambia respectively.

Objective: The main objective of the paper is to look into the latent consequences of Biotechnology

\section{Interpretations}

Case 1: In the article titled A biotechnology story: notes from India reflects an optimistic science that would beacon India on space, Atomic energy and green revolution, but also has foreshadowed a sudden loom on its dispossession. The social construction of biotechnology as the master of human sciences of food and sustainability suddenly became an iron caged rationality concept rather than a rational-legal authority, when issues of farmer suicides because of crop failure came to existence. Biotechnology predicted to be the backbone of the country but remained an imaginative entity refrained by the social discourse from documenting it. MS Swaminathan created a paradigm in itself, the father of the green revolution in India and had the notion of establishing a symbiotic social contract between society and science. The concept of sustainability became core to Swaminathan, where the upheaval of the Brundtland's newborn trajectory interacted three new dimensions for Swaminathan.

The dimensions of ecology, economics and equity were encompassed in the realm. His optimism was reflected through his proposal of the sustainable livelihood security Index in 1991. His concept of bio village also added to this. The concept aliens for pro-poor, pro- 
women, and pro-nature, sustainable agriculture and rural development. This keeps the concept of sustainability alive because of the philosophy which undertakes development to the environmentally compatible, economically efficient and socially equitable.

The iron cage rationality of green revolution was realized by MS Swaminathan when the profit exploitation yielding was slowed down, lands losing its fertility because of usage of modern technological machines and fertilizers. The main catalyst for the rising green revolution was biotechnology. The fear among the Indian farmers on encountering biotechnology was represented by the Karnataka Rajya Ryota Sangha (KRRS) headed by Nanjimdaswamy. The three turbulent events represented how farms did not have a good repo with biotechnology. The event of KFC (Kentucky Fried Chicken), the event of the international caravan, Attack on Monsanto field station conducting trials on BT cotton.

An incident of a farmer named Venkat Reddy negotiated between debt and death by selling his kidney to repay the loans that met with loses from purchasing seeds of no yielding capacity. Though this incident is not related to biotechnology, the farmers were not optimistic to trials on their lands as many were sharecroppers and had to negotiate between debts and death for profit and loss. Therefore protests took place against Monsanto field stations. This paradox has left hundreds of farmers into grief and agony as many leading to the tentacles of suicide by ending live as an escape mechanism to debts of the forcing moneylenders.

This situation juxtaposes the vulnerability of the world's poorest farmers. Protesters enchant the vision of Venkat Reddy's suicide into their protests, where if India embraces the new corporate high tech seeds, leading to more suicides and kidney sales shortly. The dialectics is seen through domination, where 700 million people are directly dependent on farming in a country like India. And this paves the way for infiltrating the agriculture, therefore conquering the agriculture leads to conquering the nation. And this platform sets the dice for the corporate houses like Monsanto. In the 21st century, the vision of direct domination is over, but the vision of indirect domination begins. Shiva, 1999 says that the benchmark for controlling nature is generated through the forces of creativity. The women folk were engaged in reproduction, on the contrary man were engaged in the process of production, where they monopolised creativity.

Case 2: The country of Zambia is a poor developing country landlocked on all sides by African countries like Mozambique, Malawi, Zimbabwe, Tanzania, Angola, Democratic Republic of Congo and Namibia. The country has a paradox of being rich in natural resources but still lives in a haunting reality of debts to external sources because of unemployment rates and low income. This paradox is added more to the plight because of neverending social problems in the country such as HIV, poverty, lack of access to safe drinking water, electricity, lack of health and hygiene facilities. Two of the important resources sets an optimistic notion for Zambia, the mining sector and the agriculture sector. The country comprises of more than 80,000 farmers (Simwanda, et al 2004). The farmers cultivate grains of two types, Cassava and Maize. Where cassava is encompassed into the northern Zambian society and Maize is encompassed into the southern Zambian society.

Society in Zambia is culturally rich in food habits; Zambia comes into the context of the study of green crime because of Zambia making headlines in various international platforms and media houses, the reason being that Zambian president refusing to accept GM food, referring to it as poison. The people of the country have supported the president on being a partisan towards the inequality of food and revolting against the notion altering the cultural practices and also the alteration of the food chain because of the conquest for penetration of genetic technology into the chain. The authorities of Zambia thinking of the ill effects of biotechnology in terms of polluting biodiversity and eventually creating a zone of economic dependence is perceived with research and study, which further juxtaposes unmilled US grain donations transported into Zambia for the pursuit of growing illegal GM crops (Nottingham, 2003).

Various forums criticized the Zambian government for inciting proliferation of hunger into the country and pulling other African countries like Ethiopia, Mozambique and Zimbabwe into hunger by opposing US grain donations. To retrospect on the claim, the Zambian authorities pulled over scientists and resources for travelling overseas with specific remit to verify the claim of the future of GM crops in Zambian soil and to comment on the government's adoption of the precautionary principle of rejection of GM grains. The fact-finding initiative concluded with results of uncertainty for the safety of the GM crops and hence it told the government to maintain the current stand by not accepting GM food, or else it could jeopardize the biodiversity and contamination of indigenous Zambian maize varieties. This episode brought Zambia into a series of criticism and being portrayed as anti genetic technology. But for Zambia, the main paradox is not with biodiversity per se but with GM donations. Zambia still uses Biotechnology that aims to reduce animal diseases and on ways that explores the benefits of medicines. The Dialectics of the opposition of GM is embedded into the opposition of the forces that pressurizes for accepting GM.

A riot took place in the southern part of Zambia where maize is grown because of immediate withdrawal of GM maize by the US despite Zambians clear opposition to Zambian foods. Accusations are on the US side by the Zambian agricultural minister for instigating riots to necessity the acceptance of GM maize (Jonathan, 2004). Apart from maize, the US and UK are keen on exporting GM cotton seeds for maximizing yield which is again opposed by Zambian authorities. The US leads to a notion that Zambian authorities are prosecuted 
as criminals, because of Zambia not letting to accept GM maize and starving their population to death and for this, the Zambian authorities should be punished harshly because of the crime against humanity. But the Zambian authorities perceive this as a political economy of interests. The optimism of the US for the promotion of GM crops is questionable when cigarette companies like Philip Morris USA refuse to accept GM tobacco from international Growers (Philip Morris, USA 2004). Therefore this contradiction distinguishes the propagation for economic growth rather than humanitarian relief and poverty reduction.

The Need For Green Criminology: The paradox of domination for the proliferation of GM by powerful institutes subjugates poor nation through the exploitation of law and international relations for vested economic and political interests. GM food which instigates human and animal safety requires a notion of criminological intervention, setting for the legitimating of Green criminology as a subject matter with an interdisciplinary approach. The exploitation of the powerful also needs a criminological dimension where transnational green crimes study comes into being. These activities of man have accumulated environmental risks and environmental harm which has disturbed the balance in our ecosystem and keeping the living as well as the nonliving, including the humans itself in a state of risk. If this continues the humanity has in the past, present and in the future has to pay a price (Saxena, 2002).

This price comes in the form of destruction of a higher impact such as the Bhopal gas tragedy of India, Kuwaiti Oil fires, Love Canal, the Exxon Valdez disaster, Tokaimura Nuclear plant accident, Seveso Dioxin cloud, Minamata Disease, Three Mile Island accident etc. to mitigate and prevent such kind of crime the countries across the globe including India has come up with legislative and non-legal measures and to restrict the happenings of certain activities and indulgence in such activities are termed as offences, environmental crimes are there in the prescription of penalties and punishment for the involvement in the activities which harms the nature. This has led to the notion of crime to be revisited and a new corner of crime arrives which has to study the disturbing effects on the environment, including the living as well as the nonliving.

\section{CONCLUSION}

Crime is inevitable and is part of every society in our globe. No society possess free from crime and criminal activities. The volume of crime may differ from place to place. The definition of crime has certain legal and epistemological gaps. Certain jurists have defined crime in terms of sociological phenomena. Crime is an act which may be intentional or omission in violation of criminal law committed without any defence or justification and penalized by the law as felony or misdemeanour. Jurist Salmond has defined crime to be something which is deemed by law to be contributing to something which is deemed by law to be contributing to some amount of harm to the society, such harm may victimize the society as a whole or victimize the individual as an immediate victim. Crime is legal harm, which is encompassed to not only the individual but also the society. Crime is something which depends on time and space. Jurisprudence also plays a role in terms of punishing criminals. The taxonomy of crime may change from place to place and society to society. The difference in state policies, subjects to differ from state to state which differs in terms of an activity for its identification to be termed as a criminal activity. An activity that might not be termed as a crime in the present may be termed as a crime in future owing to its depth and the perception of democratic structure.

The discourse of green criminology has been born from the habituation of environmental issues and criminology. Thus the whole theme of green crime is been adopted from outside the domain of conventional criminology to make such that the issues of environment are taken into it which is outside the criminological field concerning the pattern of greater environmental issues at reach. This leads to the extension of mainstream criminology to encompass the events and dynamics of the broader realm of crime signifying at a large scale global level. Enacting such an approach into the episteme of conventional criminology and thus generating a habitus to respond to environmental harm will emancipate the attributes of green crime.

The binding of nature in terms of human beings are related to the institutions of issues related to health, poverty, and the rights of the people and so on. This creates a dependency of the humans towards the establishment of the need accumulation from the environment. Humans from time immemorial have been dependent on the environment for his needs for accommodation, food, medicine, health and hygiene. Thus until and unless the vision of Biotechnology in terms of genetically modified crops is perceived without paradox or pessimism the notion of environmental harms and hazards would be embedded into the discourse and the debate on the political economy will continue to exist which will again set the platform for a green criminology subject matter.

\section{ACKNOWLEDGEMENTS}

I gratefully acknowledge support from Dibrugarh University for helping with the research work

Declaration of ownership: This report is our original work.

\section{Conflict of interest: None.}

Ethical clearance: This study was approved by the institution.

\section{REFERENCES}

Cohen, S., 1993. Human rights and crimes of the state: the culture of denial. Australian \& New Zealand Journal 
of Criminology, 26(2), pp.97-115.

Green, P.J. and Ward, T., 2000. State crime, human rights, and the limits of criminology. Social Justice, 27(1 (79), pp.101-115.

Harle, V. ed., 1978. The political economy of food. Gower Publishing Company.

Jonathan, A., 2004. Zambia refuses GM foods.

Mulaney, E., Kane, D., Rzepnicki, T. and Gambrill, E., 2004. Ethical Child Welfare Practice: Volume 2, Supervision and Administration.

Nottingham, S., 2003. Eat your genes: how genetically modified food is entering our diet. Zed Books.

Philip Morris USA. 2004. Company Information Shiva, V., 1999. Monocultures, monopolies, myths and the masculinization of agriculture. Development, 42(2), pp.35-38.

Simwanda, L. and Mwala, J., 2004. Fact Finding Mission on GMOs by Zambian Delegation to South Africa. Lusaka: Zambia Trade and Investment Enhancement Project.(20046),'Access to Genetic Resources in
Zambia', African Perspectives to Law: Access to Genetic Resources. London: Environmental Law Institute.

Situ, Y. and Emmons, D., 1999. Environmental crime: The criminal justice system's role in protecting the environment. Sage Publications.

Sutherland, E.H., 1983. White collar crime: The uncut version. Yale University Press.

Tappan, P.W., 1947. Who is the Criminal?. American Sociological Review, 12(1), pp.96-102.

Tombs, S., 2007. 'Violence', safety crimes and criminology. The British Journal of Criminology, 47(4), pp.531-550.

Walters, R., 2006. Crime, bio-agriculture and the exploitation of hunger. British Journal of Criminology, 46(1), pp.26-45.

White, R., 2003. Environmental issues and the criminological imagination. Theoretical Criminology, 7(4), pp.483-506.

White, R., 2013. Crimes against nature: Environmental criminology and ecological justice. Routledge. 